\title{
Postharvest conservation of alstroemeria 'ajax' using 1-methylcyclopropene
}

\section{Conservação pós-colheita de alstroémeria 'ajax' com uso de 1-metilciclopropeno}

\author{
Vanessa Cury Galati ${ }^{1 *}$, Ana Carolina Corrêa Muniz², João Emmanuel Ribeiro Guimarães ${ }^{2}$, \\ Carlos Orlando Inestroza-Lizardo33, Claudia Machado Fabrino Mattiuz ${ }^{4}$, Ben-Hur Mattiuz ${ }^{2}$
}

${ }^{1}$ Centro Universitário de Votuporanga/UNIFEV, Votuporanga, SP, Brasil

¿Universidade Estadual Paulista "Júlio de Mesquita Filho"/UNESP, Faculdade de Ciências Agrárias e Veterinárias, Jaboticabal, SP, Brasil

${ }^{3}$ Universidad Nacional de Agricultura, Departamento de Producción Vegetal, Catacamas, Honduras

4Universidade de São Paulo/USP, Escola Superior de Agricultura "Luiz de Queiroz"/ESALQ, Piracicaba, SP, Brasil

*Corresponding author: vanessagalati@bol.com.br

Received in August 21, 2016 and approved in January 23, 2017

\begin{abstract}
Cut flowers deteriorate quickly and require postharvest technologies to increase their durability, which is usually around 8 days. Due to the scarce information related to postharvest physiology of Alstroemeria cut flowers, this study aimed to verify the best dose of 1-methylcyclopropene (1-MCP) to the postharvest conservation of inflorescences of Alstroemeria cv. Ajax, considering the factors associated with floral senescence and loss of the decorative life. The stems were submitted to four doses of 1-MCP $(0 ; 100 ; 250 ; 500 \mathrm{ppb})$, then placed in containers with distilled water and stored at room temperature $\left(22^{\circ} \mathrm{C}\right)$. The treatments were performed in triplicate containing three stems per replicate. The evaluations were performed every three days for a total of 12 days of storage. An $F$ test was conducted, and the means were compared by the Tukey test $(p \leq 0.05)$. Among the applied treatments the dose of $500 \mathrm{ppb}$ of 1-MCP reduces the loss of water of the stems of alstroemerias during the storage period, keeping the petals turgids and the levels of carotenoids and anthocyanins high, however, this was not enough to keep the decorative quality of the flowers, once the 1-MCP did not solve the problems of yellowing of the leaves and floral openning, which are important characteristics for its commercialization.
\end{abstract}

Index terms: Ethylene; longevity; pigments; enzyme activity.

\begin{abstract}
RESUMO
As flores de corte se deterioram muito rapidamente e necessitam de tecnologias pós-colheita para aumentar a durabilidade, que é normalmente em torno de 8 dias. Devido às escassas informações relacionadas à fisiologia pós-colheita de flores de Alstroeméria, a presente pesquisa teve como objetivo verificar qual a melhor dose de 1-metilciclopropeno (1-MCP) na conservação pós-colheita de inflorescências de Alstroemeria cv. Ajax, considerando os fatores associados à senescência floral e perda da vida decorativa. As hastes foram submetidas a quatro doses de 1-MCP $(0 ; 100 ; 250 ; 500 \mathrm{ppb})$, posteriormente foram colocadas em recipientes com água destilada e armazenadas em temperatura de ambiente $\left(22^{\circ} \mathrm{C}\right)$. Os tratamentos foram realizados em triplicata contendo três hastes por repetição. As avaliações foram realizadas a cada três dias perfazendo um total de 12 dias de armazenamento. Foi realizado um teste de F, e as médias comparadas pelo teste de Tukey $(P \leq 0,05)$. Entre os tratamentos aplicados a dose de $500 \mathrm{ppb}$ de 1-MCP reduziu a perda de água das hastes de alstroeméria durante o período de armazenamento, mantendo as pétalas túrgidas e os níveis de carotenoides e antocianinas altos, entretanto, isso não foi suficiente para manter a qualidade decorativa das flores, uma vez que o 1-MCP não resolveu os problemas de amarelecimento das folhas e abertura floral, que são importantes características para sua comercilização.
\end{abstract}

Termos para indexação: Etileno; longevidade; pigmentos; atividade enzimática.

\section{INTRODUCTION}

Alstroemerias (Alstroemeria hybrida L.) have shown great importance in the world trade of cut flowers due to its beauty, variety of colors, and above all, the long postharvest life of its flowers (Ferrante et al., 2002), around 8 days. However, this durability is usually prejudiced by the rapid yellowing of the leaves, which impairs the decorative quality of these flowers.

Several factors contribute to the acceleration of senescence of the cut flowers, such as transpiration, high respiratory rates, blocking of the xylem vessels, reduced supply of carbohydrates and production and sensitivity to ethylene (Celikel; Reid, 2002; 2005).

Ethylene is a plant growth regulator produced by plants that affects the longevity of cut flowers, because it induces many physiological responses such as wilting and abscission of leaves, petals and sepals, thus anticipating the senescence of these flowers (Finger et al., 1999). According to Faragher et al. (2002), the harmful effects of ethylene are responsible for approximately $30 \%$ of the losses in the floriculture sector. 
Ethylene inhibitors are being used to prevent the action of this regulator, among them is the 1-metilcloropropeno (1-MCP) (Mattiuz, 2005) which is a volatile and non-toxic compound that interferes in the plant metabolism by delaying its senescence (Isapareh; Hatamzadeh; Ghasemnejad, 2014). This is a competitive inhibitor because it has an affinity 10 times higher than the ethylene to the receptor sites, allowing its irreversible binding to these sites, preventing the physiological stimulus of the ethylene (Blankenship; Dole, 2003; Chitarra; Chitarra, 2005).

Delays in floral senescence using 1-MCP were observed in many species, such as alpinias (Mattiuz, 2005), roses (Pietro; Mattiuz; Mattiuz, 2010), oriental lilies (Celikel et al., 2002), geraniums (Cameron; Reid, 2001; Jones et al., 2001) and orchids (Moraes et al., 2007). Serek, Sisler and Reid (1995) observed that the use of 1-MCP increased the vase life of Alstroemeria cut flowers. According to those authors this is one of the cut flowers that respond to ethylene by the petals abscission.

Due to the scarce informations related to postharvest physiology of alstroemeria cut flowers, this study aimed to verify the best dose of 1-methylcyclopropene to the postharvest conservation of inflorescences of Alstroemeria cv. Ajax, considering the factors associated with floral senescence and loss of the decorative life.

\section{MATERIAL AND METHODS}

To carry out this research it were used Alstroemeria cut flowers cv. Ajax of red color, grown in Andradas, Minas

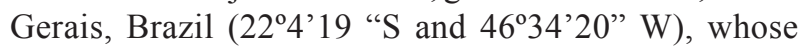
stems were collected in the morning at the maturation point where the primary flowers showed the color and were about to open. Then, they were transported under refrigeration to the Laboratory of Postharvest of the FCAV-UNESP, campus of Jaboticabal-SP, where they were standardized at $70 \mathrm{~cm}$ in length and the leaves that were in contact with the solutions were removed.

To generate the 1-MCP in gaseous form, the commercial product Ethylbloc ${ }^{\circledR}$ was used in the form of wettable powder containing $0.14 \%$ of 1 -MCP.

The Alstroemeria stems were placed inside hermetic chambers and exposed to the 1-MCP in gaseous form, for a period of 6 hours, at the following concentrations: 0 (control); 100; 250 and $500 \mathrm{ppb}$. Subsequently, they were transferred to Erlenmeyer flasks containing $500 \mathrm{~mL}$ of distilled water. For each treatment were used three replications with three stems each. The flowers were stored at room temperature $\left(22 \pm 3{ }^{\circ} \mathrm{C}\right)$ and $85 \pm 4 \% \mathrm{RH}$ and the experiment was conducted in a completely randomized design.

Every three days were evaluated the variation of fresh mass; the relative water content (Kramer, 1983); the levels of carotenoids and anthocyanins (Francis, 1982; Lichtenthäler, 1987); the levels of soluble and reducing carbohydrates (Mattiuz et al., 2010); the activity of the enzymes polyphenol oxidase and peroxidase (Adnan; Augustin; Ghazali, 1986; Matsuno; Uritani, 1972).

To the floral longevity it was separated a set of stems with their respective treatments to evaluate the following parameters of the decorative quality of Alstroemeria flowers: floral opening, color of leaves, anthers falling and turgidity of flowers. For this evaluation was given a rating scale ranging from 5 to 1 , where: Note 5 (maximum score): the flowers were $100 \%$ closed and $100 \%$ turgid, the leaves were $100 \%$ green, and had $100 \%$ of the anthers; Note $4: 75 \%$ of flowers opened and $75 \%$ turgid, leaves $75 \%$ green and had $75 \%$ of the anthers; Note 3: the flowers were $50 \%$ opened and $50 \%$ turgid, the leaves $50 \%$ green and $50 \%$ had anther; Note $2: 25 \%$ of flowers opened and $25 \%$ turgid, $25 \%$ of green leaves and had $25 \%$ of the anthers; Note 1: $100 \%$ of flowers opened and wilted and the leaves completely yellowed, and there was no presence of anthers on the flowers, according to the methodology described by Galati et al. (2015). The completion of this evaluation occurred when the flowers presented darkening, abscission, withered petals and yellowing of the leaves.

The results were submitted to analysis of variance (ANOVA) and the effect of the treatments, when significant, to the F Test. The means were compared by Tukey Test $(\mathrm{p} \leq 0.05)$. When differences between treatments were greater than the sum of the standard deviation, the result was considered significant (Steel; Torrie, 1987).

\section{RESULTS AND DISCUSSION}

Alstroemeria stems treated with 1-MCP at 100 and $500 \mathrm{ppb}$ absorbed the distilled water during all days of storage. In contrast, the control and the $250 \mathrm{ppb}$ treatment started losing fresh mass from the $3^{\text {rd }}$ day of storage (Figure 1).

From the $6^{\text {th }}$ day of storage there were significant differences among the treatments and it was verified that the stems treated with 100 and $500 \mathrm{ppb}$ of 1-MCP showed the highest relative water content in the flowers throughout the storage (Figure 2). These results are in agreement with those found for fresh mass (Figure 1), being a determining factor in the maintenance of the quality of the plants. 


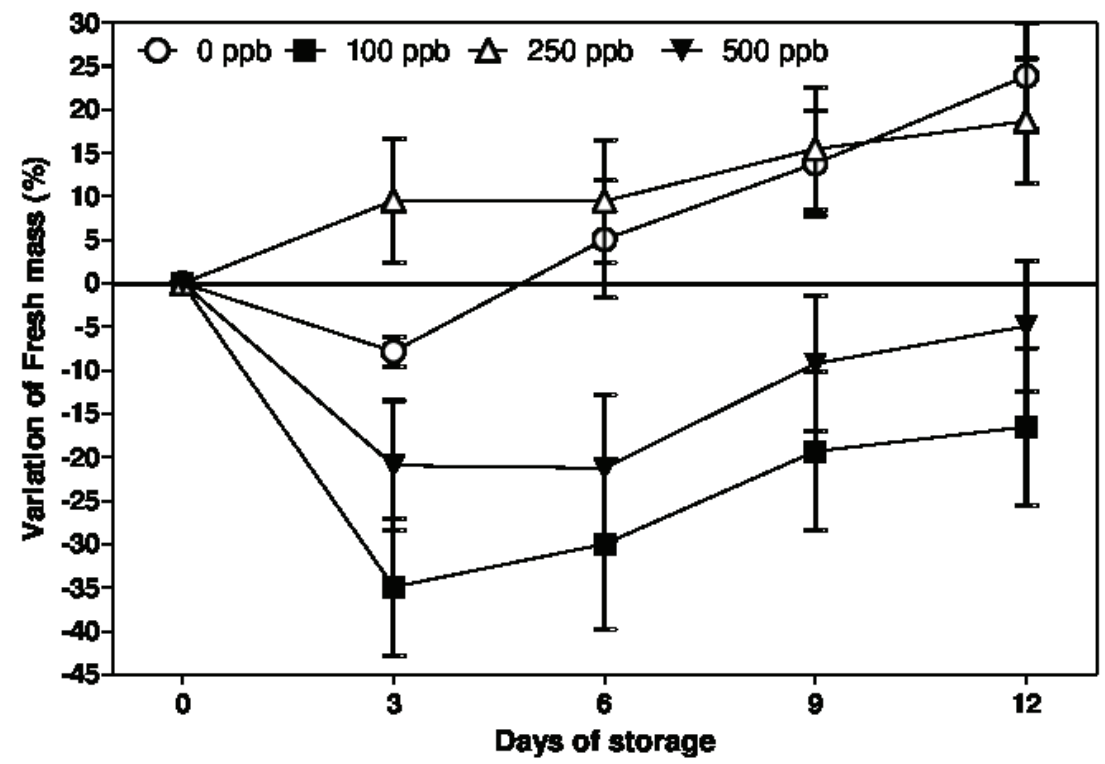

Figure 1: Variation of fresh mass, in percentage, of 'Ajax' alstroemerias stems exposed to different concentrations of $1-\mathrm{MCP}$ and maintained at $22 \pm 3^{\circ} \mathrm{C}$ and $85 \pm 4 \% \mathrm{RH}$ during 12 days. Vertical bars represent the standard error of the mean.

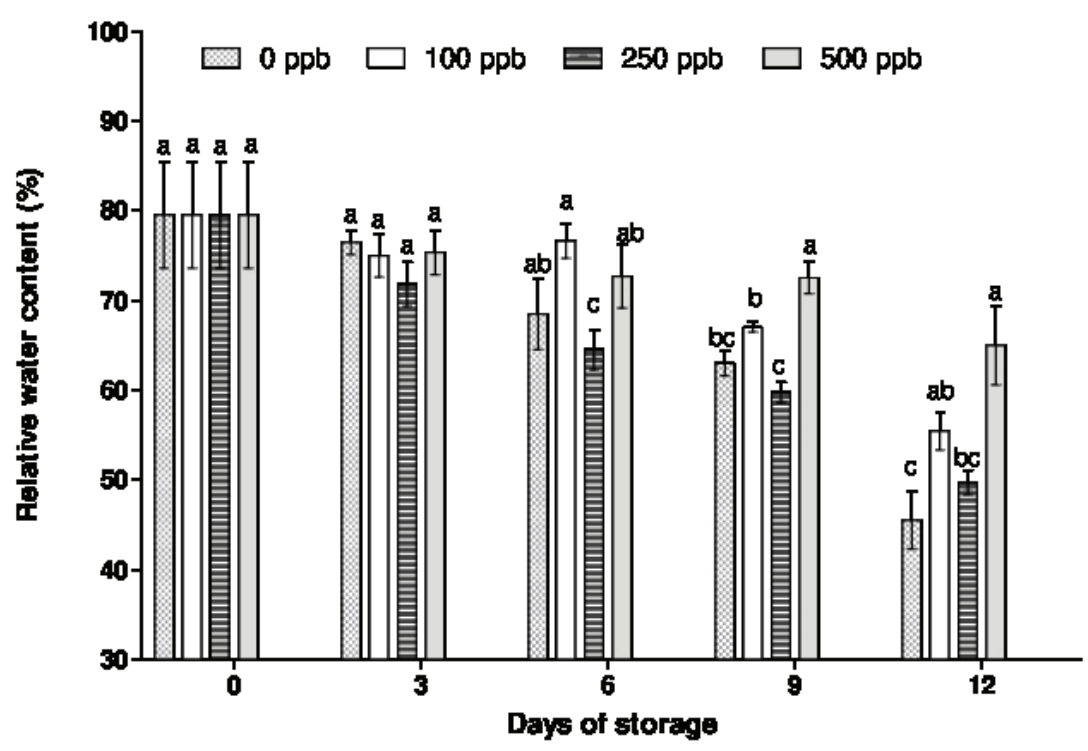

Figure 2: Relative water content in 'Ajax' alstroemerias stems exposed to different concentrations of 1-MCP and maintained at $22 \pm 3^{\circ} \mathrm{C}$ and $85 \pm 4 \% \mathrm{RH}$. Means followed by at least one common letter, on each day of analysis, do not differ by Tukey test $(\mathrm{P}>0.05)$. Vertical bars represent the standard error of the mean.

According to Cantillano et al. (2008), the loss of water is a senescence accelerator, causing an increase in the rate of disintegration of the membrane and loss of cell content, with consequent loss of turgor. The smallest loss of fresh mass may be due to the 1-MCP capacity of blocking the ethylene action and retard the senescence (Pietro; Mattiuz; Mattiuz, 2010). Furthermore, the application of 1-MCP can increase the water absorption of the inflorescences, indicating greater turgidity of the flowers during the storage period (Obsuwan; Uthairatanakij, 2007). 
The loss of water, or water stress during the days of life in the vessel, begins when the water content in the intracellular tissues moves away from the optimum. The water deficit can result in growth reduction, discoloration of flowers, reduction of the turgidity, increase of the susceptibility to physiological disorder caused by cold and acceleration of senescence symptoms (Kays, 1991).

For the floral longevity it was observed that the maximum flower opening was reached on the sixth day after storage for all treatments (Figure 3). From this date, it was evident that the use of 1-MCP did not delay the yellowing of the leaves, moreover, the fall of the anthers began, indicating that in the case of alstroemerias the 1-MCP did not presented significative effect on the chlorophyll degradation in the leaves, what was also observed in rocket leaves (Koukounaras; Siomos; Safakiotans, 2006). The stems of the treatment with 500 $\mathrm{ppb}$, from the ninth day of storage, began to present loss of turgor superior to the other treatments, indicating the onset of senescence of the plant.

Mattiuz et al. (2012) studying the application of different concentrations of 1-MCP in Oncidium 'Samurai' found that the highest concentration (1000 ppb) delayed the opening of the buds and kept the turgidity of the flowers throughout the storage period. This was not observed in this experiment, since the application of the ethylene inhibitor did not affect the floral opening (Wagstaff et al., 2005). It is possible that the use of higher concentrations of 1-MCP would delay the flower opening.

The respiratory activity in the alstroemerias stems progressively decreases during the storage period. Among the treatments, stems treated with $100 \mathrm{ppb}$ of 1-MCP had lower respiration rate when compared to the other concentrations (Figure 4). The increase in the respiration rate observed in this research may be due to the chemical stress caused by the application of higher doses of 1-MCP (Rosa et al., 2016).
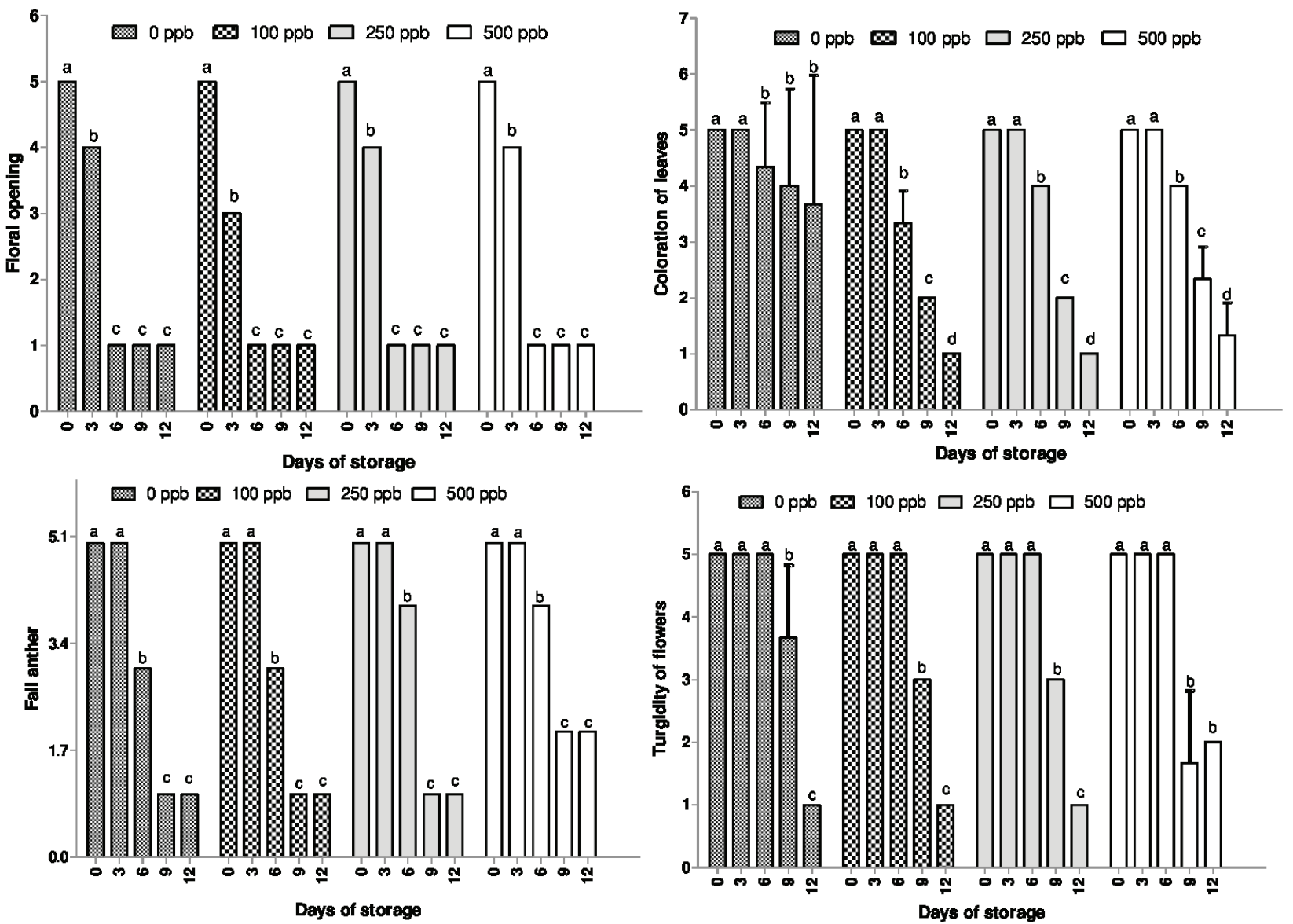

Figure 3: Qualitative characteristics of 'Ajax' alstroemerias stems exposed to different concentrations of 1-MCP and maintained at $22 \pm 3{ }^{\circ} \mathrm{C}$ and $85 \pm 4 \% \mathrm{RH}$. Vertical bars represent the standard error of the mean. 


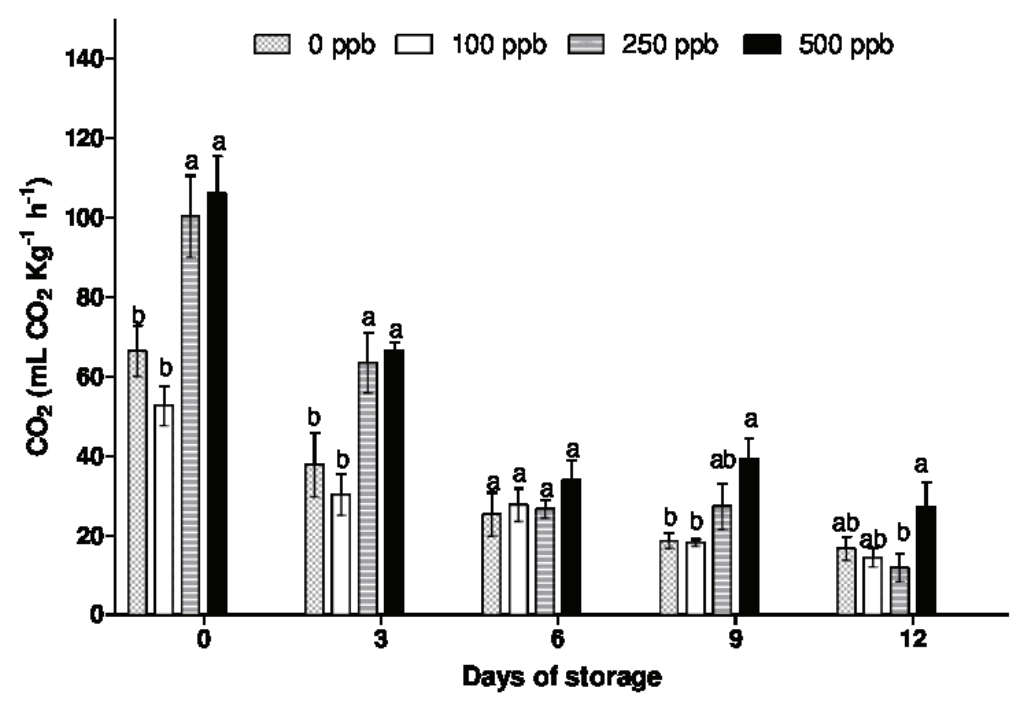

Figure 4: Respiratory rate in stems of alstroemerias 'Ajax' exposed to different concentrations of 1-MCP and maintained at $22 \pm 3{ }^{\circ} \mathrm{C}$ and $85 \pm 4 \% \mathrm{RH}$. Means followed by at least one common letter, on each day of analysis, do not differ by Tukey test $(\mathrm{P}>0.05)$. Vertical bars represent the standard error of the mean.

The longevity of a plant depends on the respiratory activity, because it is related to the growth and senescence, therefore its monitoring is important once if it is not checked, can compromises the quality, shortening the life of the plant.

The decline in respiration rate at the end of the storage period occurred simultaneously with the loss of water and the increase in the symptoms of senescence. This indicates a possible disruption of the structure of the membranes and the cytoplasmic organelles that occur during the process of senescence, resulting in decreased respiratory rate (Arciuch, 2012). This is supported by Hardenburg, Watada and Wang (1990) that argue that the cut flowers have a very limited life after harvest, surviving from its own reserves, which are usually reduced because of morphological and physiological features of tissues. In the days of storage it was observed a trend of reduction of the respiration rate, even though the statistics were not compared among days of evaluation.

The content of soluble carbohydrates in the petals of Alstroemeria flowers increased during the period in which the plants remained stored. After 12 days of storage the flowers that had the highest levels were the ones treated with $500 \mathrm{ppb}$ of 1-MCP (Figure 5A). The increase in the soluble carbohydrate content may be related to the increase in the carotenoids and anthocyanins content in the flowers, because the sugars are essential for the metabolism of the plants, also being associated with senescence of the flowers and increase in the pigments contents (Pietro et al., 2012).

According to Dong, Lurie and Zhou (2002), the reduction in the respiration rate promoted by 1 - MCP can result from an effect in the carbohydrates metabolism, proving to be more efficient in the maintenance of the contents during all postharvest period, as it was observed in this experiment.

Depending on age and water stress caused in the plants, sugars can be located, mostly in the vacuoles and not in the cytoplasm, thus, the mitochondria may not be able to use the sugars, or the cytosol of take them to the mitochondria, occurring accumulation of soluble sugars in the petals of cut flowers during the storage period (Wouter; Van Doorn, 2001).

The accumulation of carbohydrates in the cell may also be a mechanism to reduce cellular water potential, promote the absorption of water and consequently the turgor, requiring high amount of water for the development of flower buds to the stadium of full opening (Iglesias et al., 2006).

Mattiuz et al. (2012) found that the application of $1000 \mathrm{ppb}$ of 1-MCP in cut inflorescence of Oncidium 'Samurai' caused an increase in the levels of carbohydrates, a similar trend to that found in this experiment to the highest concentration of 1-MCP (500 ppb). 


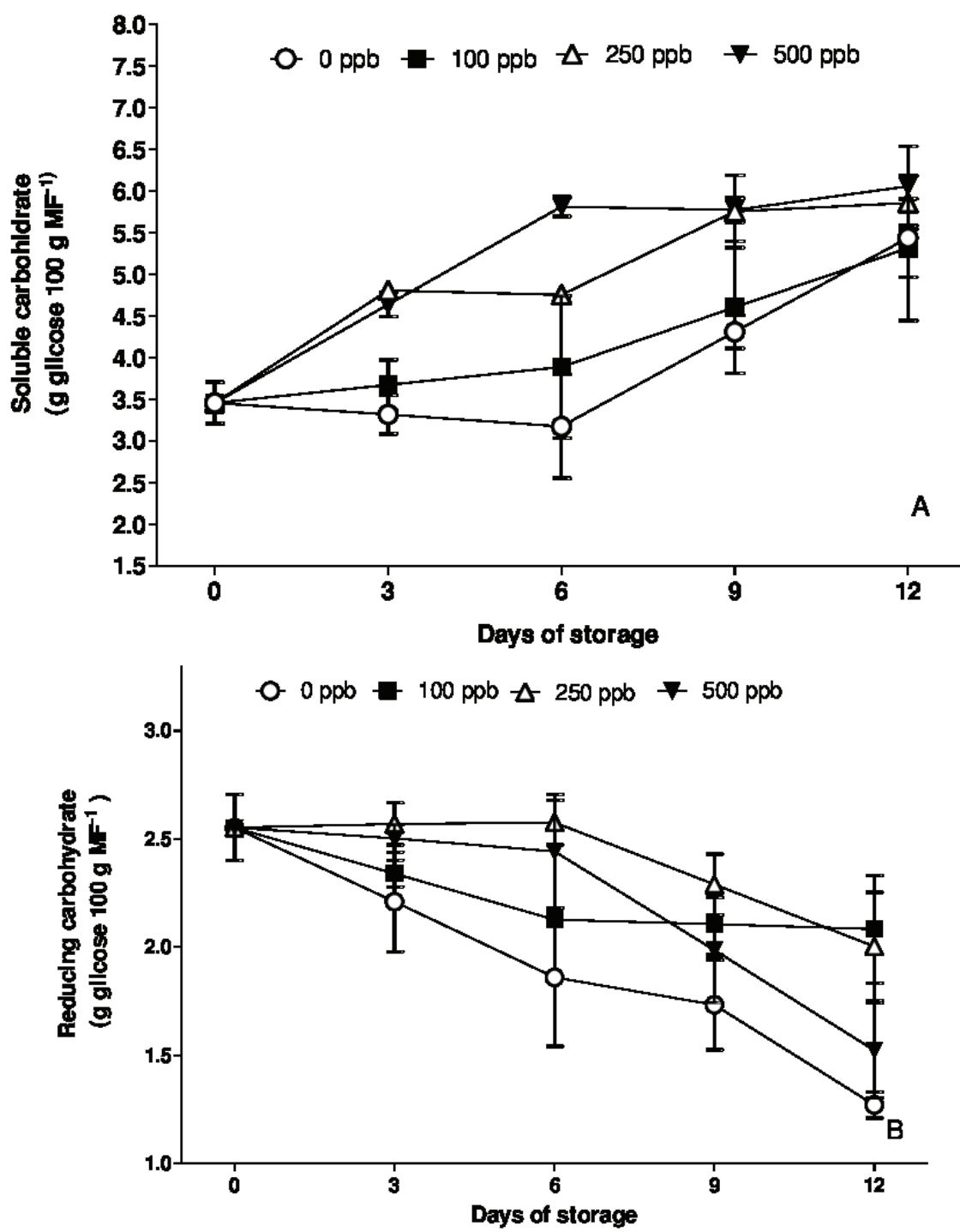

Figure 5: Soluble (A) and reducing (B) carbohydrate content in stems of Alstroemeria cv. 'Ajax' exposed to different concentrations of $1-\mathrm{MCP}$ and maintained at $22 \pm 3{ }^{\circ} \mathrm{C}$ and $85 \pm 4 \% \mathrm{RH}$. Vertical bars represent the standard error of the mean.

The reducing carbohydrate content showed a reverse trend, that is, there was a reduction of these sugars during storage. Nevertheless, it is apparent that the stems treated with 100 and $250 \mathrm{ppb}$ of $1-\mathrm{MCP}$ were those which maintained the highest values in the last days of storage (Figure 5B). The control treatment was the one that had the lowest concentrations of sugars in the petals of the flowers.

In cut roses it has been reported that some stems are incapable of absorbing sufficient amount of the solution, reducing the water potential of the cells of the petals, which can lead to increased levels of osmotically active substances in all cellular compartments (Wouter; Van Doorn, 2001).

The activity of the peroxidase enzyme increased during the storage of the flowers. The ones treated with 500 $\mathrm{ppb}$ were those with the highest activity starting on the $6^{\text {th }}$ day (Figure 6A). According to Hossain et al. (2006), the activity of peroxidase enzymes is regulated and previously programmed by the increase in the levels of peroxides in the cells, which seems to be a prerequisite for the initiation of senescence in gladiolus. 

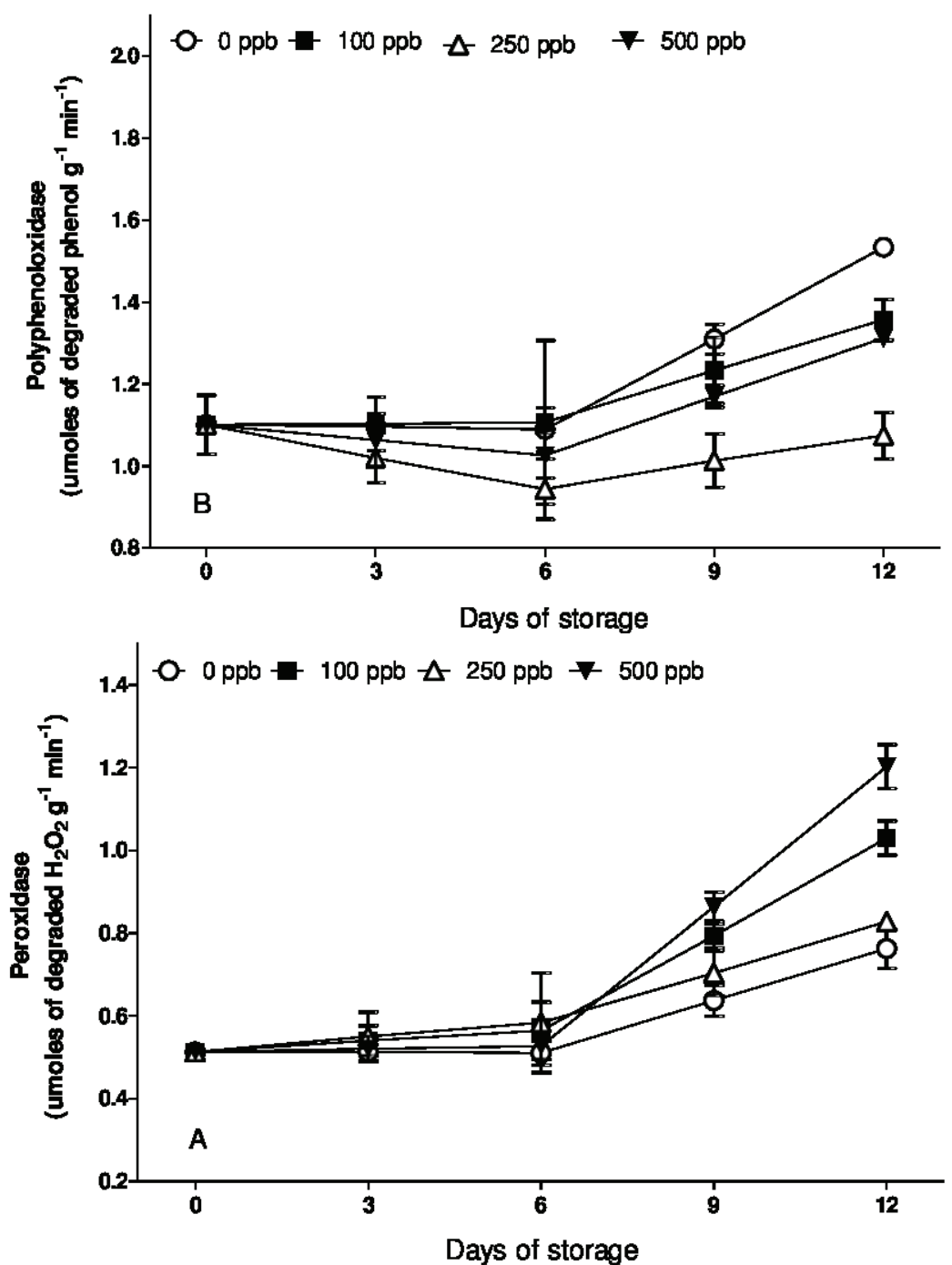

Figure 6: Activity of the enzymes peroxidase (A) and polyphenoloxidase (B) in stems of Alstroemeria cv. 'Ajax' exposed to different concentrations of $1-\mathrm{MCP}$ and maintained at $22 \pm 3^{\circ} \mathrm{C}$ and $85 \pm 4 \% \mathrm{RH}$. Vertical bars represent the standard error of the mean.

The flowers treated with 250 and $500 \mathrm{ppb}$ of 1-MCP showed lower activity of the polyphenol oxidase enzyme, explaining the absence of darkening in the flowers and can be related to the appearance of the same submitted to those treatments (Figure 6B). The darkening of the tissues occurs as a result of the disruption of the membranes, because phenolic compounds, which were stored in the vacuoles, are released or alternatively deposited on the cell walls, contacting the oxidative enzymes peroxidase and polyphenol (Nguyen; Ketsa; Van Doom, 2003).

The 1-MCP maintains the signaling route inhibited, due to the blockade of ethylene action, thus the cellular metabolism continues its functions and protects the membranes, what probably leads to the increase of the activity of oxidative fighting enzymes, such as peroxidase.

The concentration of carotenoids found in the flowers was about ten times larger than the concentration of anthocyanins (Figure 7A and 7B). The carotenoid content increased during storage period for all treatments, and the treatment of $500 \mathrm{ppb}$ of $1-\mathrm{MCP}$ was the one that provided the greatest average for both variables. This treatment was also the one that achieved the highest anthocyanin content, with the greatest concentration on the $12^{\text {th }}$ day of storage. 


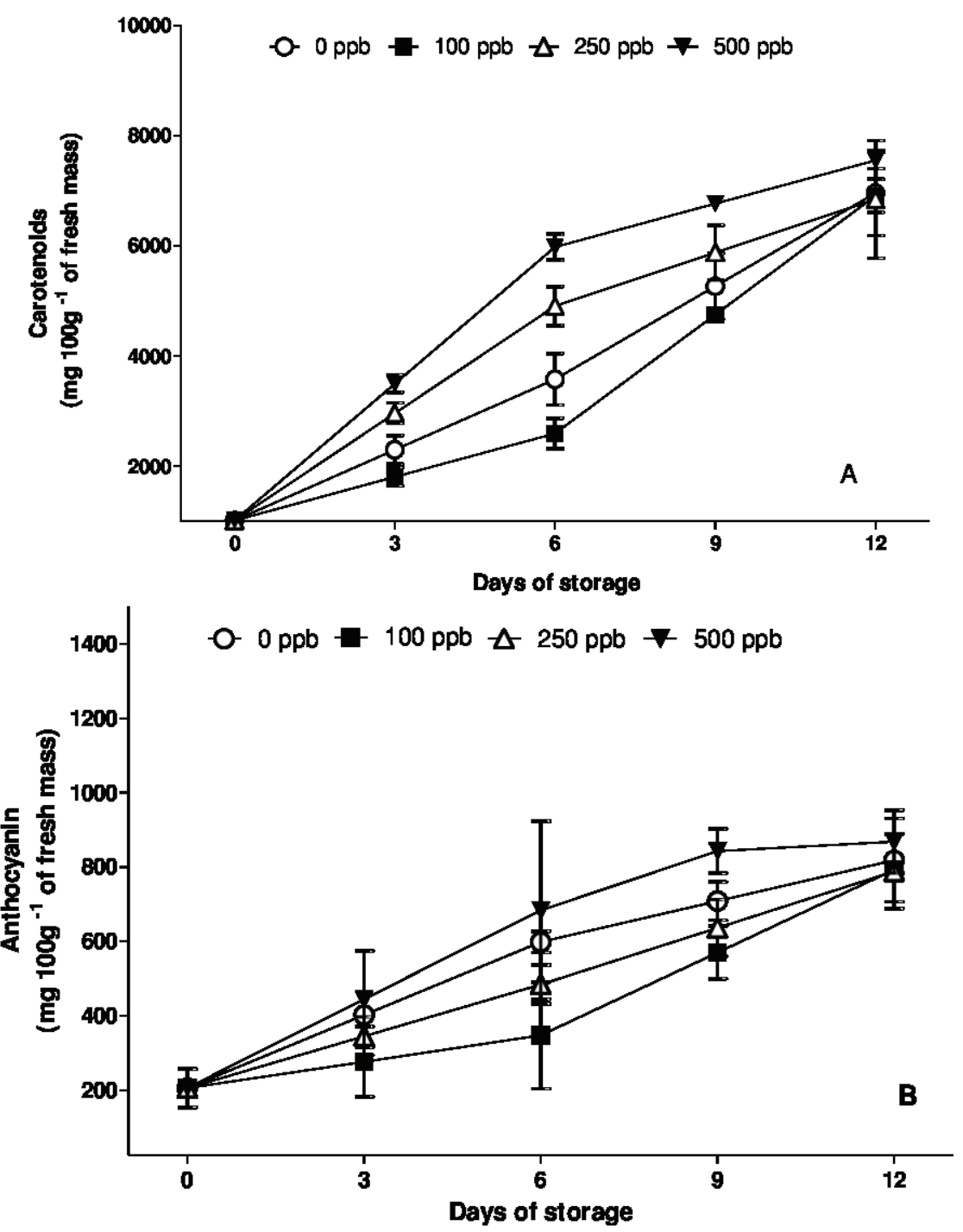

Figure 7: Carotenoid (A) and anthocyanins (B) contents in stems of Alstroemeria cv. 'Ajax' exposed to different concentrations of $1-\mathrm{MCP}$ and maintained at $22 \pm 3{ }^{\circ} \mathrm{C}$ and $85 \pm 4 \% \mathrm{RH}$. Vertical bars represent the standard error of the mean.

Skoog et al. (2001) also observed that the treatment with 1-MCP at $0.5 \mathrm{~g} \mathrm{~m}^{-3}$ for six hours, provided an increase in carotenoid content in roses, Consolida ajacis, Antirrhinum majus, gypsophila, alstroemeria, lilies and poinsettias, being the results in agreement with those found in this experiment.

According to Simpson, Baquar and Lee (1975), the increase of carotenoids and anthocyanins is related to the maturity of the flowers and not with the degeneration of the plant structure, which was observed by these researchers in Strelitzia reginae.

\section{CONCLUSIONS}

Among the applied treatments the dose of 500 ppb 1-MCP reduces the loss of water of the stems of Alstroemeria cv. Ajax during the storage period, keeping the petals turgids and the levels of carotenoids and anthocyanins high. However, this was not enough to keep the decorative quality of the flowers, once the 1-MCP did not solve the problems of yellowing of the leaves and floral openning, which are important characteristics for its commercialization. 


\section{REFERENCES}

ADNAN, T. A. B. T.; AUGUSTIN, M. A.; GHAZALI, H. M. Polyfenoloxydase from starfruit. Pertanika Journal, 9(2):219-224, 1986.

ARCIUCH, V. G. A. et al. Mitochondrial regulation of cell cycle and proliferation. Antioxid Redox Signal, 16(10):11501180, 2012.

BLANKENSHIP, S. M.; DOLE, J. M. 1-methylcyclopropene: A review. Postharvest Biology and Technology, 28(1):125, 2003.

CAMERON, A. C.; REID, M. S. 1-MCP blocks ethylene-induced petal abscission of Pelargonium peltatum but the effect is transient. Postharvest Biology and Technology, 22(2):169-177, 2001.

CANTILLANO, R. F. F. et al. Qualidade físico-química e sensorial de cultivares de morango durante o armazenamento refrigerado. Boletim de Pesquisa e Desenvolvimento, Embrapa Clima Temperado. Pelotas, RS, 2008. 29p.

CELIKEL, F. G.; REID, M. S. Storage temperature affects the quality of cut flowers from the Asteraceae. HortScience, 37:148-150, 2002

CELIKEL, F. G.; REID, M. S. Temperature and postharvest performance of rose (Rosa hybrida L. 'First Red') and gypsophila (Gypsophila paniculata L. 'Bristol Fairy') flowers. Acta Horticulturae, 682:1789-1794, 2005.

CHITARRA, M. I. F.; CHITARRA, A. B. Pós-colheita de frutos e hortaliças: Fisiologia e manuseio. 2. ed. revisada e ampliada. Lavras: UFLA, 2005. 785p.

DONG, L.; LURIE, S.; ZHOU, H. W. Effect of 1-methylcyclopropene on ripening of 'Canino' apricots and 'Royal Zee' plums. Postharvest Biology and Technology, 24(2):135-145, 2002.

FARAGHER, J. et al. Postharvest handling of australian flowers from australian native plants and related species, a practical workbook. Rural Industries Research and Development Corporation, Australian, n. 02/021, 2002. 216p.

FERRANTE, A. et al. Thidiazuron - A potent inhibitor of leaf senescence in Alstroemeria. Postharvest Biology and Technology, 25(3):333-338, 2002.

FINGER, F. L. et al. Influence of ethephon, silver thiosulfate and sucrose pulsing on bird of paradise vase life. Revista Brasileira de Fisiologia Vegetal, 11(2):119-122, 1999.
FRANCIS, F. J. Analysis of anthocyanins. In: MARKARIS, P. Anthocyanins as food colors. New York: Academic Press, p.182-205, 1982

GALATI, V. C. et al. Use of calcium chloride in postharvest treatment of Alstroemeria cut flowers. Acta Horticulturae (ISHS), 1104(41):267-272, 2015.

HARDENBURG, R. E.; WATADA, A. E.; WANG, C. Y. The commercial storage of fruits, vegetables and floristand nursery stocks. Agriculture Research Service, Canada, 1990. 130p.

HOSSAIN, Z. et al. Decline in ascorbate peroxidase activity a prerequisite factor for tepal senescence in gladiolus. Journal of Plant Physiology, 163(2):186-194, 2006.

IGLESIAS, D. J. et al. Carbohydrate and ethylene levels regulate citrus fruitlet drop through the abscission zone a during early development. Trees, 20(1):348-355, 2006.

ISAPAREH, A.; HATAMZADEH, A.; GHASEMNEJAD, M. The effect of natural essential carvacrol and some growth regulators on vase life of Alstroemeria cut flowers. Journal of Ornamental Plants, 4(2):115-122, 2014

JONES, M. L.; KIM, E. S.; NEWMAN, S. E. Role of ethylene and 1 -MCP in flower development and petal abscission in zonal geraniums. HortScience, 36(7):1305-1309, 2001.

KAYS, J. S. Postharvest physiology of perishable plant products. New York: Van Nostrand Reinhold, 1991. 453p.

KRAMER, P. J. Water relations of plants. New York: Academic Press, 1983, 489p.

KOUKOUNARAS, A.; SIOMOS, A. S.; SAFAKIOTANS, E. 1-Methylcyclopropene prevents ethylene induced yellowing of rocket leaves. Postharvest Biology and Tecnology, 41:109-111, 2006

LICHTENTHALER, H. K. Chlorophylls and carotenoids: Pigments of photosynthetic biomembranes. Methods in Enzymology, 148(22):350-382, 1987.

MATSUNO, H.; URITANI, I. Physiological behavior peroxidase isozynes in sweet potato root tissueinjuried by cuting or black rot. Plant and Cell Physiology, 13(6):1091-1101, 1972.

MATTIUZ, C. F. M. et al. Efeito de agentes químicos na conservação pós-colheita de inflorescências de Alpinia purpurata (Vieill) K. Schum. Revista Brasileira de Plantas Ornamentais, 11(4):35-42, 2005.

MATTIUZ, C. F. M. et al. Water relations of cut inflorescences of Alpinia purpurata treated with seven pulsing solutions. Acta Horticulturae, 1(683):363-368, 2005. 
MATTIUZ, C. F. M. et al. Armazenamento refrigerado de inflorescências cortadas de Oncidium varicosum 'Samurai', Ciência Rural, 40(11):2288-2293, 2010.

MATTIUZ, C. F. M. et al. Longevity of Oncidium varicosum (Orchidaceae) inflorescences treated with 1 methylciclopropene. Ciência Rural, 42(6):987-992, 2012.

MORAES, P. J. et al. Longevidade pós-colheita da orquídea Epidendrum ibaguense. Revista Brasileira de Horticultura Ornamental, 13(1):31-37, 2007.

NGUYEN, T. B. T.; KETSA, S.; VAN DOOM, W. G. Relationship between browning and the activities of polyphenoloxidase and phenylalanine ammonialyase in banana peel during low temperature storage. Postharvest Biology and Technology, 30(2):187-193, 2003.

OBSUWAN, K.; UTHAIRATANAKIJ, A. The responses of different cut inflorescence of orchid hybrids to various 1-MCP concentrations. Acta Horticulturae, 3(755):465-470, 2007.

PIETRO, J.; MATTIUZ, B. H.; MATTIUZ, C. F. M. Influência do 1-MCP na conservação pós-colheita de rosas cv. Vega. Ciência e Agrotecnologia, 34(5):1176-1183, 2010.

PIETRO, J. et al. Manutenção da qualidade de rosas cortadas cV. Vega em soluções conservantes. Horticultura Brasileira, 30(1):64-70, 2012.
ROSA, C. I. L. F. et al. Effect of 1-MCP on the postharvest quality of the orange cv. Pera store under refrigeration. Revista Ciência Agronômica, 47(4):624-632, 2016.

SEREK, M.; SISLER, E. C.; REID, M. S. Effects of I-MCP on the vase life and ethylene response of cut flowers. Plant Growth Regulate, 16(4):93-97,1995.

SKOOG, L. J. et al. A survey of ethylene contamination in Ontario's floriculture industry and the evaluation of 1-methylcyclopropene and an ethylene absorber as potential solutions. Acta Horticulturae, 543(5):55-62, 2001.

SIMPSON, D. J.; BAQUAR, M. R.; LEE, T. H. Ultrastructure in carotenoids composition of chromoplasts of the sepals of Strelitzia reginae Aiton during floral development. Annals of Botany, 39(2):175-183, 1975.

STEEL, R. G. D.; TORRIE, J. H. Principles and procedures of statistics: A biometrical approach. 2.ed., McGraw Hill, USA. p.272-277, 1987.

WAGSTAFF, C. et al. Ethylene and flower longevity in Alstroemeria: Relationship between tepal senescence, abscission and ethylenebiosynthesis. Journal of Experimental Botany, 56(413):1007-1016, 2005.

WOUTER, G.; VAN DOORN, W. G. Role of soluble carbohydrates in flower senescence: A survey. Acta Horticulturae, 543(6):179-183, 2001. 